\title{
Originals
}

\section{Contrasting action of short- and long-term adrenaline infusion on dog skeletal muscle glucose metabolism}

\author{
M.J.Christopher ${ }^{1}$, M.W.Sleeman ${ }^{1}$, F.P.Alford ${ }^{2}$ and J.D. Best ${ }^{1}$ \\ ${ }^{1}$ Department of Medicine, University of Melbourne, and ${ }^{2}$ Endocrine Unit, St. Vincent's Hospital, Fitzroy, Victoria, Australia
}

\begin{abstract}
Summary. There are important differences between the short- and long-term effects of adrenaline on determinants of glucose tolerance. To assess this metabolic adaptation at tissue level, the present study examined the effect of acute and prolonged in vivo elevation of adrenaline on glycogen metabolism and glycolysis in skeletal muscle. Adrenaline (50 $\mathrm{ng} \cdot \mathrm{kg}^{-1} \cdot \min ^{-1}$ ) was infused for $2 \mathrm{~h}$ or $74 \mathrm{~h}$ and the results compared with $1 \mathrm{~h} 0.9 \% \mathrm{NaCl}$ infusion in six trained dogs. Muscle glycogen content was reduced by long-term adrenaline ( $161 \pm 17 \mathrm{vs} \mathrm{NaCl} 250 \pm 24 \mu \mathrm{mol} / \mathrm{g}$ dry weight; $p<0.05)$ but not short-term adrenaline $(233 \pm 21)$ indicating a sustained effect of adrenaline on glycogen metabolism. Acutely, glycogen synthase I was reduced (short-term adrenaline $12 \pm 6 \mathrm{vs} \mathrm{NaCl} 22 \pm 7 \mu \mathrm{mol}$ glycosyl units $\cdot \mathrm{g}^{-1} \cdot \mathrm{min}^{-1} ; p<0.05$ ) but returned to normal with prolonged adrenaline infusion $(20 \pm 5)$. In contrast, $K_{\mathrm{m}}$ for glycogen phosphorylase $a$ was not changed acutely (short-term adrenaline $31 \pm 6 \mathrm{vs} \mathrm{NaCl}$ $27 \pm 7 \mathrm{mmol} / \mathrm{l}$ inorganic phosphate) but was reduced during long-term infusion $(19 \pm 4 ; p<0.05$ vs short-term adre-
\end{abstract}

naline). Thus, with short- and long-term adrenaline infusion, there were different enzyme changes, although likely to promote glycogenolysis in both cases. In the glycolytic pathway the substrates glucose 6-phosphate and fructose 6-phosphate did not change significantly and hexokinase was not inhibited. Acutely, phosphofructokinase had reduced $V_{\max }$ (short-term adrenaline $34 \pm 6$ vs $\mathrm{NaCl} 44 \pm 5 \mathrm{U} / \mathrm{g} ; p<0.05$ ) but was still above the maximal operating rate in vivo. With prolonged adrenaline infusion, the $\mathrm{K}_{\mathrm{m}}$ for phosphofructokinase was reduced (long-term adrenaline $0.32 \pm 0.03$ vs $\mathrm{NaCl}$ $0.44 \pm 0.07 \mathrm{mmol} / \mathrm{l}$ fructose 6 -phosphate; $p<0.05$ ). In this situation of relatively low glycolytic flux, the sustained glycogenolytic effect of prolonged adrenaline infusion mediated by increased glycogen phosphorylase $a$ ctivity occurs without a significant accumulation of hexose monophosphates or impairment of glycolysis.

Key words: Adrenaline, glycogen metabolism, glycolysis, hexose monophosphates.
In situations of severe physical stress there is increased mobilisation of fuels such as glucose, fatty acids and ketone bodies, brought about by increased secretion of stress hormones, including adrenaline (ADR) [1]. ADR plays an important role in the regulation of these fuels, acting directly on hepatic and peripheral tissues [2] as well as indirectly, through modulation of insulin secretion [3]. The overall effect of physiological elevations of ADR on steady-state metabolism is to produce hyperglycaemia and increase levels of non-esterified fatty acids $[4,2]$.

The insulin-sensitive tissue of major importance for glucose disposal is skeletal muscle [5]. Decreased glucose uptake by mammalian skeletal muscle due to ADR was described 40 years ago [6], although in other in vitro studies $A D R$ has been shown to produce either inhibition or stimulation of glucose uptake $[7,8]$. In vivo studies have consistently shown impairment of insulin-stimulated glucose disposal by ADR, although few have looked spe- cifically at the role of skeletal muscle $[9,10]$. One study which examined muscle glucose metabolism in vivo has shown impairment by ADR of glucose uptake into muscles with high oxidative capacity but not into muscles with predominantly glycolytic fibres [10].

It has been proposed that one mechanism for impairment of glucose uptake by ADR is the accumulation of metabolites in the glycolytic pathway [9-11], with inhibition of the hexokinase reaction, particularly by glucose 6-phosphate [12]. Accumulation of glucose 6-phosphate will depend on the rate of input from glycogenolysis as well as the rate of output via glycolysis. ADR has well-documented actions to promote glycogenolysis $[9,11]$ but its actions on glycolysis are not as well defined. Accumulation of glucose 6-phosphate will also depend on the prevailing plasma insulin and glucose levels. An increased rate of transmembrane glucose transport would tend to promote glucose 6-phosphate accumulation with sub- 
Table 1. Effect of adrenaline on plasma concentrations of metabolites and hormones in blood samples obtained just before induction of anaesthesia. Samples were obtained after $1 \mathrm{~h} 0.9 \% \mathrm{NaCl}, 2 \mathrm{~h}$ (short) or $74 \mathrm{~h}$ (long) adrenaline infusion $\left(50 \mathrm{ng} \cdot \mathrm{kg}^{-1} \cdot \mathrm{min}^{-1}\right.$ )

\begin{tabular}{lccc}
\hline & $\mathrm{NaCl}$ & \multicolumn{2}{c}{ Adrenaline infusion } \\
\cline { 3 - 4 } & & short & long \\
\hline Adrenaline $(\mathrm{pg} / \mathrm{ml})$ & $91 \pm 18$ & $486 \pm 52^{\mathrm{a}}$ & $872 \pm 153^{\mathrm{b}}$ \\
Glucose $(\mathrm{mmol} / \mathrm{l})$ & $5.1 \pm 0.2$ & $5.7 \pm 0.3$ & $5.3 \pm 0.3$ \\
Insulin $(\mathrm{mU} / \mathrm{l})$ & $13 \pm 4$ & $11 \pm 3$ & $7 \pm 2^{\mathrm{c}}$ \\
Glucagon $(\mathrm{pg} / \mathrm{ml})$ & $65 \pm 21$ & $80 \pm 18$ & $59 \pm 34$ \\
Cortisol $(\mu \mathrm{mol} / \mathrm{l})$ & $0.04 \pm 0.01$ & $0.04 \pm 0.01$ & $0.05 \pm 0.01$ \\
Noradrenaline $(\mathrm{pg} / \mathrm{ml})$ & $238 \pm 48$ & $289 \pm 76$ & $318 \pm 33$ \\
Non-esterified fatty & & & \\
acids $(\mathrm{mmol} / \mathrm{l})$ & $0.61 \pm 0.13$ & $1.01 \pm 0.16^{\mathrm{a}}$ & $0.90 \pm 0.17$ \\
\hline
\end{tabular}

${ }^{\mathrm{a}} p<0.001$ vs NaCl; ${ }^{\mathrm{b}} p<0.01 \mathrm{vs} \mathrm{NaCl} ;{ }^{\mathrm{c}} p<0.05 \mathrm{vs} \mathrm{NaCl}$ and short; ${ }^{d} p<0.05$ vs $\mathrm{NaCl}$.

Results given as mean $\pm \mathrm{SEM}, n=6$

sequent reduction from the high rate of transport. However, if insulin is elevated, its effects on enhancement of glycolysis and glycogen synthesis will act to reduce glucose 6-phosphate levels [13]. The net effect of ADR on glucose 6-phosphate accumulation will depend on the balance between these various influences.

Prolonged elevation of ADR produces attenuation of some of the acute effects on glucose metabolism. Insulin sensitivity in vivo is restored to normal and glucose uptake by isolated skeletal muscle can actually be increased by prolonged administration of ADR [14]. However, not all aspects of glucose metabolism may be normalised by longterm ADR. After 74-h ADR infusion in normal dogs we found a sustained reduction of glucose tolerance, despite normal insulin sensitivity [15]. Insulin secretory parameters were the same as control values, so the most likely explanation for the reduced glucose tolerance was a sustained impairment of glucose-mediated glucose disposal, that is the ability of glucose to promote its own disposal independent of a rise in insulin [16].

This present study was designed to assess in vivo the effects of short-term and long-term ADR infusions on enzymes and substrates related to glucose metabolism in skeletal muscle. With short-term ADR infusion, we examined action on enzymes regulating glycogen metabolism and glycolysis, as well as effects on accumulation of substrates. During long-term infusion, we looked at which actions of ADR on skeletal muscle glucose metabolism were attenuated and which were sustained.

\section{Materials and methods}

\section{Animals}

The studies were carried out with the permission of the Experimental Medical and Surgical Research Ethics Committee at St. Vincent's Hospital on six dogs of mixed breed, $18-28 \mathrm{~kg}$ body weight. After induction of anaesthesia, a femoral or jugular vein was catheterised with silicone tubing and the catheter tip advanced towards the right atrium. The other end was routed to the back where it exited be- tween the scapulas and the catheter was filled with heparinised saline and capped, with the free end placed in a small bag inside a pocket of a jacket worn by the dog, for easy access.

\section{Protocol}

Dogs were used in studies at least one week after surgery, provided they appeared healthy, and had a leucocyte count of $<18 \times 10^{\circ} /$. All dogs were trained to lie quietly during the studies, and each dog underwent three studies at least two weeks apart in the following order: 1) $0.9 \% \mathrm{NaCl}$ infusion for $1 \mathrm{~h}$;2) ADR infusion at $50 \mathrm{ng}$. $\mathrm{kg}^{-1} \cdot \mathrm{min}^{-1}$ for $2 \mathrm{~h}$; and 3) ADR infusion at $50 \mathrm{ng} \cdot \mathrm{kg}^{-1} \cdot \mathrm{min}^{-1}$ for $74 \mathrm{~h}$.

In dogs fasted for $18 \mathrm{~h}$, an infusion catheter was placed in the cephalic vein of one foreleg and a butterfly needle was inserted into the cephalic vein of the opposite foreleg for blood sampling. After at least a 20 -min relaxation period, samples were obtained for basal measurements of plasma glucose, insulin, glucagon, catecholamines, cortisol and non-esterified fatty acids. The blood samples were collected into tubes containing appropriate anticoagulants and preservatives [15], placed on ice, centrifuged within $1 \mathrm{~h}$ and the separated plasma frozen and stored at $-20^{\circ} \mathrm{C}$ until assayed.

In the short-term studies, the infusion of ADR solution (Adrenalin Injection. Boots, North Rocks, Australia, given in $0.9 \% \mathrm{NaCl}$ containing $0.5 \mathrm{~g} / \mathrm{ml}$ of ascorbic acid) or $0.9 \% \mathrm{NaCl}$ was then commenced. At the end of the infusion period, further blood samples were obtained. In the long-term studies, ADR was infused via the indwelling intravenous catheter by a small infusion pump (Syringe Driver - Type MS16 or MS16A., Pye Dynamics, Herts, UK) carried by the dog in its jacket. After $72 \mathrm{~h}$, the ADR infusion was switched to the same non-portable infusion pump as that used for the short-term studies (PSA 50 Secan Toulouse, France). This change was made to ensure identical ADR infusion rates for at least $2 \mathrm{~h}$ prior to the muscle biopsy procedure. After 74 h of the long-term infusion, blood samples were collected. During the $74 \mathrm{~h}$ h ADR infusion, dogs were fed a standard daily diet of $0.6 \mathrm{~kg}$ dog chow $(70 \%$ min crude protein, $2.5 \%$ min crude fat) and $0.4 \mathrm{~kg} \mathrm{dog}$ biscuit $(15 \%$ min crude protein, $10 \%$ min crude fat, $5 \%$ max crude fibre). Feeding was monitored daily to ensure that the dog had eaten his daily supply of food. There was no change in the physical activity or behaviour of the dogs during these infusions.

For muscle biopsy the dogs were anaesthetised using the shortacting barbiturate thiopentone ( $40 \mathrm{mg} / \mathrm{kg} \mathrm{i.v.),} \mathrm{intubated} \mathrm{and} \mathrm{anaes-}$ thesia maintained with nitrous oxide/oxygen. At the time of muscle biopsy, all dogs had been fasting for $19.5 \mathrm{~h}$ to $20.5 \mathrm{~h}$. The skin and fascia $8-12 \mathrm{~cm}$ above the patella on the lateral portion of the thigh were anaesthetised with local anaesthetic ( $2 \%$ xylocaine), and a $3-\mathrm{cm}$ incision was made through skin and fascia with a scalpel. Using at least two $5 \mathrm{~mm}$ Bergström biopsy needles (Stilhe, Stockholm, Sweden), a total of 4 or 5 muscle samples (averaging about $40 \mathrm{mg}$ wet weight each) were obtained from the vastus lateralis, frozen immediately (within $<7 \mathrm{~s}$ ) in liquid nitrogen and stored at $-80^{\circ} \mathrm{C}$ until analysed. Vastus lateralis is predominantly a fast-twitch red muscle, composed of $78 \%$ fast-twitch red, $18 \%$ fast-twitch white and $4 \%$ slow-twitch red fibres [17], with a high aerobic-oxidative and glycolytic capacity. In each dog, the left leg was biopsied in studies 1 and 3 (with lateral incisions made at least $4 \mathrm{~cm}$ apart) and the right leg was biopsied in study 2.

\section{Laboratory analysis}

Plasma glucose was measured with an automatic analyser (Yellow Springs Instruments, Yellow Springs, Ohio, USA) using a glucose oxidase method. Plasma insulin and glucagon were estimated by radioimmunoassay using dextran-coated charcoal separation of bound and free fractions. Kit methods were used for measurement of plasma catecholamines by radioenzymatic assay (CAT-A-KIT, 
Table 2. Effect of adrenaline on glycogen and hexose monophosphates in dog skeletal muscle. Samples were obtained by muscle biopsy after $1 \mathrm{~h} 0.9 \% \mathrm{NaCl}, 2 \mathrm{~h}$ (short) or $74 \mathrm{~h}$ (long) adrenaline infusion $\left(50 \mathrm{ng} \cdot \mathrm{kg}^{-1} \cdot \mathrm{min}^{-1}\right)$

\begin{tabular}{llll}
\hline $\begin{array}{l}\text { Substrate } \\
(\mu \mathrm{mol} / \mathrm{g} \text { dry weight })\end{array}$ & $\mathrm{NaCl}$ & \multicolumn{2}{c}{ Adrenaline infusion } \\
\cline { 3 - 4 } & & short & long \\
\hline Glycogen & $250 \pm 24$ & $\begin{array}{c}233 \pm 21 \\
(n=5)\end{array}$ & $161 \pm 17^{\mathrm{a}}$ \\
Glucose 6-phosphate & $1.63 \pm 0.41$ & $2.08 \pm 0.48$ & $1.99 \pm 0.65$ \\
Fructose 6-phosphate & $0.79 \pm 0.29$ & $0.30 \pm 0.07$ & $0.38 \pm 0.20$ \\
\hline
\end{tabular}

a $p<0.05$ vs $\mathrm{NaCl}$ and short.

Results given as mean $\pm \mathrm{SEM}, n=6$

Amersham, Cardiff, UK), non-esterified fatty acids by an enzymatic colorimetric method (Wako Pure Chemical Industries, Osaka, Japan) and plasma cortisol by radioimmunoassay (Clinical assay, Gamma coat, Baxter Healthcare Corporation, Cambridge, Mass., USA).

\section{Kinetic studies of muscle enzymes}

The activities of the glycolytic enzymes, hexokinase, phosphofructokinase and pyruvate kinase were measured spectrophotometrically at $30^{\circ} \mathrm{C}, \mathrm{pH} 7.4$, in a final volume of $2.5 \mathrm{ml}$ using matching glass cuvettes ( $10 \mathrm{~mm}$ light path) by following the changes in optical density due to the oxidation or reduction of pyridine nucleotides at $340 \mathrm{~nm}$ on a SP8-100 Pye-Unicam ultra violet Double-Beam Spectrophotometer. The hexokinase, phosphofructokinase and pyruvate kinase assays were adapted from the methods described by Doery et al. [18]. Total hexokinase activity was measured at $2.0 \mathrm{mmol} / \mathrm{glu}-$ cose only; phosphofructokinase activity was measured at $0,0.3,0.7$, 1.4 and $4.0 \mathrm{mmol} / \mathrm{l}$ fructose 6 -phosphate, producing a regulatory sigmoidal dose-response curve, and pyruvate kinase activity was measured at $0.05,0.12,0.30$ and $1.00 \mathrm{mmol} / 1$ phosphoenolpyruvate, producing a non-regulatory hyperbolic dose-response curve. Similarly, glycogen phosphorylase (GP) was assayed at $\mathrm{pH} 6.8$ in the direction of glycogen breakdown using an adaptation of the method described by Bergmeyer [19]. GP activity was measured at constant glycogen level $(0.2 \%$ weight/volume $)$ both in the absence and presence of $2.0 \mathrm{mmol} / \mathrm{AMP}$ at $10,25,45$ and $100 \mathrm{mmol} / \mathrm{lnorganic}$ phosphate, allowing determination of GP $a$ and total GP $(a+b)$ activities respectively. Glycogen synthase (GS) was assayed at $\mathrm{pH} 7.4$ in the direction of glycogen synthesis using a method adapted from Danforth [20] and Kornfeld \& Brown [21]. The reaction was started by the addition of uridine diphospho-glucose, and the formation of uridine diphosphate was measured spectrophotometrically via the coupled pyruvate kinase-lactate dehydrogenase reaction. GS activity was measured both in the absence and presence of $10 \mathrm{mmol} / \mathrm{glu}-$ cose 6-phosphate at $3.0 \mathrm{mmol} / \mathrm{l}$ uridine diphospho-glucose, allowing determination of GS I and total GS $(I+D)$ activities respectively.

To measure the activities of the glycolytic enzymes, hexokinase, phosphofructokinase and pyruvate kinase in skeletal muscle, a small piece of frozen muscle (10-15 $\mathrm{mg}$ wet weight) was weighed accurately, homogenised in glycolytic homogenisation buffer [22] using a 1-ml capacity tissue grinder, separated from insoluble connective tissue and brought to a concentration of $10 \mathrm{mg} / \mathrm{ml}$. The homogenate was then sonicated with $3 \times 10 \mathrm{~s}$ bursts and centrifuged at $4^{\circ} \mathrm{C}, 8000 \mathrm{~g}$ for $30 \mathrm{~s}$. The supernatant was then stored on ice until ready for enzymatic spectrophotometric analysis.

To measure the activities of GP and GS, separate homogenates were prepared using a glycogen-storage enzyme homogenisation buffer containing the same concentration of reagents as glycolytic homogenisation buffer, but with the addition of $25 \mathrm{mmol} / \mathrm{l}$ sodium fluoride and $2 \mathrm{mmol} / 1$ EGTA to prevent the activities of specific protein phosphatases and $\mathrm{Ca}^{2+}$-dependent protein kinases respec- tively. To measure GP activity, about $10 \mathrm{mg}$ muscle wet weight was homogenised to a concentration of $10 \mathrm{mg} / \mathrm{ml}$, sonicated, centrifuged, and the supernatant stored at $4^{\circ} \mathrm{C}$ until ready for enzymatic spectrophotometric analysis. To measure GS activity, about $30-40 \mathrm{mg}$ muscle wet weight was homogenised in $750 \mu \mathrm{l}$ buffer, sonicated and centrifuged as described above, and duplicate aliquots of the supernatant were incubated in a reaction mixture $\left(750 \mu\right.$ total volume) for $45 \mathrm{~min}$ at $37^{\circ} \mathrm{C}$ in the direction of uridine diphosphate production for subsequent enzymatic spectrophotometric analysis.

Enzymic activities were calculated after subtraction of the appropriate reagent blank reaction rate. Results are expressed as umol of substrate utilised per gramme of muscle wet weight per min $(\mathrm{U} / \mathrm{g})$ (mean \pm SEM).

\section{Substrate measurements}

Glycogen was determined in perchloric acid extracts of muscle (about $20 \mathrm{mg}$ wet weight) using a modification of the method described by Keppler \& Decker [23]. Glucose 6-phosphate and fructose 6-phosphate were measured sequentially in perchloric acid extracts of muscle (about $40-50 \mathrm{mg}$ wet weight) using a modification of the method described by Gerhard [24]. As with the enzyme kinetic analysis, all substrates were measured spectrophotometrically at $340 \mathrm{~nm}\left(25^{\circ} \mathrm{C}, 10 \mathrm{~mm}\right.$ light path) by following the changes in optical density due to the oxidation or reduction of pyridine nucleotides. The muscle content of each substrate was calculated after subtraction of the appropriate reagent blank activity. Results are expressed as $\mu \mathrm{mol}$ substrate per gramme of muscle dry weight (mean $\pm \mathrm{SEM}$ ).

\section{Statistical analysis}

Statistical analyses were performed using two-way analysis of variance or paired Student's $t$-test. In this study, the intra-assay variation was $<10 \%$, and the interassay variation was $<20 \%$ for all enzymes and substrates measured.

Table 3. Effect of adrenaline on phosphofructokinase, pyruvate kinase and hexokinase kinetics in dog skeletal muscle. Samples were obtained by muscle biopsy after $1 \mathrm{~h} 0.9 \% \mathrm{NaCl}, 2 \mathrm{~h}$ (short) or $74 \mathrm{~h}$ (long) adrenaline infusion $\left(50 \mathrm{ng} \cdot \mathrm{kg}^{-1} \cdot \mathrm{min}^{-1}\right.$ )

\begin{tabular}{lccc}
\hline & $\mathrm{NaCl}$ & \multicolumn{2}{c}{ Adrenaline infusion } \\
\cline { 3 - 4 } & & short & long \\
\hline $\begin{array}{l}\text { Phosphofructokinase } \\
\text { Total (U/g) at 4.0 mmol/ }\end{array}$ & & & \\
fructose 6-phosphate & $42 \pm 5$ & $32 \pm 5^{\mathrm{a}}$ & $36 \pm 3$ \\
$\mathrm{~K}_{\mathrm{m}}$ (mmol/1) & $0.44 \pm 0.07$ & $0.46 \pm 0.12$ & $0.32 \pm 0.03^{\mathrm{a}}$ \\
$\mathrm{V}_{\max }(\mathrm{U} / \mathrm{g})$ & $44 \pm 5$ & $34 \pm 6^{\mathrm{a}}$ & $37 \pm 3$ \\
$\begin{array}{l}\text { Pyruvate kinase } \\
\text { Total (U/g) at } 1.0 \mathrm{mmol} / \mathrm{l}\end{array}$ & & & \\
phosphoenolpyruvate & $566 \pm 93$ & $555 \pm 70$ & $517 \pm 97$ \\
$\mathrm{~K}_{\mathrm{m}}$ (mmol/1) & $0.10 \pm 0.02$ & $0.10 \pm 0.01$ & $0.08 \pm 0.01$ \\
$\begin{array}{l}\text { Vmax } \\
\text { Hexokinase }\end{array}$ & $670 \pm 64$ & $616 \pm 76$ & $594 \pm 86$ \\
$\begin{array}{l}\text { Total (U/g) at } 2.0 \mathrm{mmol} / \mathrm{l} \\
\text { glucose }\end{array}$ & $0.29 \pm 0.04$ & $0.37 \pm 0.09$ & $0.34 \pm 0.04$ \\
\hline
\end{tabular}

${ }^{a} p<0.05$ vs NaCl.

Results given as mean $\pm \mathrm{SEM}, n=6$ 


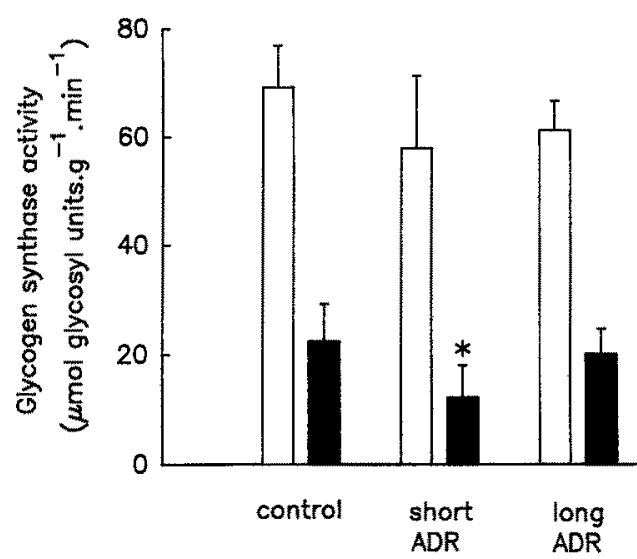

Fig. 1. Effect of adrenaline (ADR) on glycogen synthase (GS) activity (mean $+\mathrm{SEM}, n=5$ for short $\mathrm{ADR}, n=6$ for $\mathrm{NaCl}$ and long ADR) in dog skeletal muscle. Muscle was biopsed after $2 \mathrm{~h}$ (short ADR) or $74 \mathrm{~h}$ (long ADR) adrenaline infusion $\left(50 \mathrm{ng} \cdot \mathrm{kg}^{-1} \cdot \mathrm{min}^{-1}\right.$ ) or after $1 \mathrm{~h} 0.9 \% \mathrm{NaCl}$. Activity of GSI (active form) (w) was determined in the absence of glucose 6-phosphate, and total GS activity $(\mathrm{I}+\mathrm{D})(\square)$ was determined in the presence of $10 \mathrm{mmol} / \mathrm{l}$ glucose 6 phosphate, using a constant level of uridine diphospho-glucose ( $3.0 \mathrm{mmol})$ and glycogen $(1 \%$ weight/volume). $* p<0.05$ vs $\mathrm{NaCl}$ and long ADR

\section{Results}

Effect of adrenaline on plasma levels of metabolites and hormones

As shown in Table 1, ADR levels were $91 \pm 18 \mathrm{pg} / \mathrm{ml}$ during the $\mathrm{NaCl}$ infusion, indicating that the dogs were not stressed. During the 2-h infusion of ADR at $50 \mathrm{ng}$. $\mathrm{kg}^{-1} \cdot \min -1$ (short ADR), plasma ADR concentration increased four to six-fold ( $\mathrm{p}<0.001)$. After the 74-h infusion (long ADR) the levels tended to be even higher. Plasma concentrations of glucose, glucagon, noradrenaline and cortisol did not change significantly during the three treatments. Plasma insulin was unchanged by short ADR even though glucose tended to rise, but significantly reduced by long ADR $(p<0.05)$. Non-esterified fatty acids were elevated in the short-term $(p<0.05)$, but at $74 \mathrm{~h}$, although still tending to be high they were not significantly different from control values.

\section{Effect of adrenaline on muscle enzymes and substrates}

As shown in Table 2, muscle glycogen content was significantly reduced by long ADR $(p<0.05)$ but not short ADR. This reduction of glycogen content over $74 \mathrm{~h}$ corresponds to a glycogenolytic rate of about $5 \mu \mathrm{mol} \cdot \mathrm{kg}^{-1}$ wet weight. $\mathrm{min}^{-1}$. Figure 1 shows GS I $(0 \mathrm{mmol} / \mathrm{l}$ glucose 6-phosphate) and total GS $[\mathrm{I}+\mathrm{D}](10 \mathrm{mmol} / \mathrm{l}$ glucose 6-phosphate) in the three treatments. GS I was significantly reduced during short ADR compared with $\mathrm{NaCl}$ ( $12 \pm 6$ vs $22 \pm 7 \mu$ mol glycosyl units $\cdot \mathrm{g}^{-1} \cdot \min ^{-1} ; p<0.05$ ) but not long ADR (20 \pm 5$)$. Total GS and the GS activity ratio (GS I/GS $[I+D]$ ) did not change significantly with short- or long-term ADR. The A 0.5 for the allosteric activator glucose 6-phosphate is considered to be a more sensitive measure than the GS activity ratio as an index of the phosphorylation state of GS [25, 26], but there was insuffi- cient muscle to obtain a glucose 6-phosphate doseresponse curve in this study.

The effect of adrenaline on GP in the absence of AMP (GPa) is shown in Figure 2. At the physiological level of $10 \mathrm{mmol} / \mathrm{l}$ inorganic phosphate [11], GP $a$ was significantly reduced by long ADR $(p<0.05)$. $\mathrm{K}_{\mathrm{m}} a$ determined by Eadie-Hofstee plots showed reduction by long ADR (19 $\pm 4 \mathrm{mmol} / \mathrm{l}$ inorganic phosphate) compared with short ADR $(31 \pm 6 \mathrm{mmol} / \mathrm{l} ; p<0.05)$ which did not differ from $\mathrm{NaCl}(27 \pm 7 \mathrm{mmol} / \mathrm{l}) . \mathrm{V}_{\max }$ of $\mathrm{GP} a$ was unchanged by short or long ADR. In the presence of $2 \mathrm{mmol} / 1 \mathrm{AMP}$ when both GPa and $b$ are active, the $\mathrm{K}_{\mathrm{m}}$ of total GP $\left(\mathrm{K}_{\mathrm{m}} a+b\right)$ was unchanged by short and long ADR ( $\mathrm{NaCl}$ $4.0 \pm 0.4 \mathrm{mmol} / /$ inorganic phosphate; short ADR $3.4 \pm 0.4 \mathrm{mmol} / 1$; long ADR $3.5 \pm 0.4 \mathrm{mmol} / \mathrm{l}) . \mathrm{V}_{\max }$ of total GP also did not change with either short ADR or long ADR.

The kinetics of phosphofructokinase are described in Table 3. Phosphofructokinase had reduced $V_{\max }$ during short ADR $(p<0.05)$ but not long ADR, and the sigmoidal plot of the results for short ADR was significantly reduced compared with the plot for $\mathrm{NaCl}(p<0.05$, two-way analysis of variance). On the other hand, the $K_{m}$ for phosphofructokinase was significantly reduced by long ADR $(p<0.05)$ compared with $\mathrm{NaCl}$ but not short ADR. The sigmoidal plot produced by the phosphofructokinase activities during long $\mathrm{ADR}$ returned towards $\mathrm{NaCl}$ values. Table 3 also shows the effect of the three treatments on hexokinase and pyruvate kinase and Table 2 shows results for the glycolytic substrates glucose 6-phosphate and fructose 6-phosphate.

\section{Discussion}

In this study we assessed changes of skeletal muscle glucose metabolism after in vivo infusion of $A D R$ for $2 \mathrm{~h}$ and compared the effects with infusion for $74 \mathrm{~h}$. Comparable

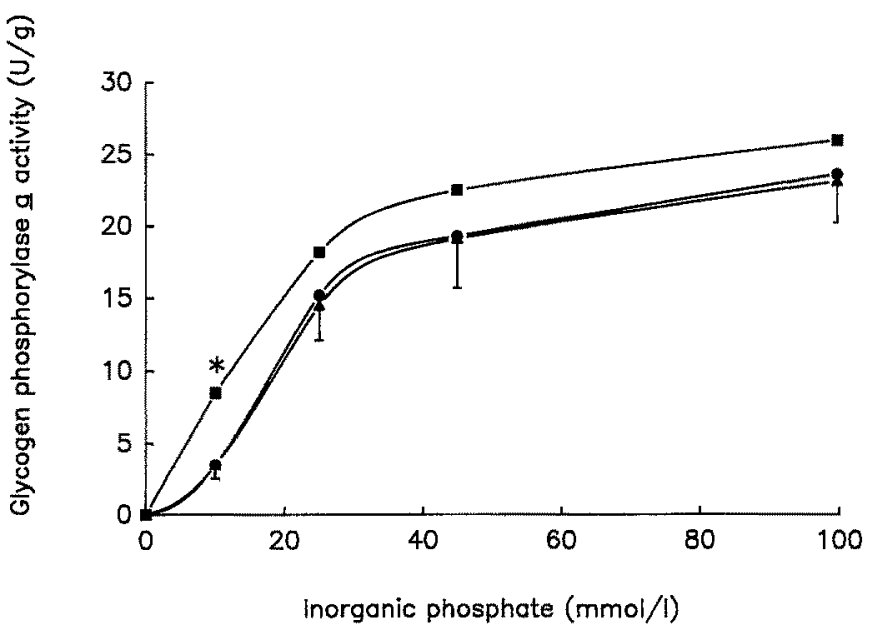

Fig.2. Effect of adrenaline on glycogen phosphorylase $a(\mathrm{GPa})$ activity in dog skeletal muscle (mean $\pm \mathrm{SEM}, n=6$ ). Muscle was biopsied after $2 \mathrm{~h}$ (short ADR) (A) or $74 \mathrm{~h}$ (long ADR) ( $)$ adrenaline infusion $\left(50 \mathrm{ng} \cdot \mathrm{kg}^{-1} \cdot \mathrm{min}^{-1}\right)$ or after $1 \mathrm{~h} 0.9 \% \mathrm{NaCl}(\bullet) . \mathrm{GP} \mathrm{a}$ activity was determined in the absence of AMP using a constant level of glycogen $\left(0.2 \%\right.$ weight/volume). ${ }^{*} p<0.05 \mathrm{vs} \mathrm{NaCl}$ and short ADR 
long-term elevation of plasma catecholamines in man can occur in the context of severe burns, septic shock, infusion of positive inotropic drugs and phaeochromocytoma [27]. During short-term ADR infusion, absolute glycogen synthase I was significantly reduced by $45 \%$ without any change of total glycogen synthase activity. This result is consistent with previous studies both in rabbits [28] and humans [11], showing reductions of glycogen synthase I activity after short-term administration of ADR. The mechanism for this effect involves interaction of ADR with $\beta$-adrenergic receptors causing phosphorylation and thus inactivation of glycogen synthase via cyclic AMP dependent protein kinase $[26,28]$. Sensitivity of the reaction rate to changes in the phosphorylation state of the enzyme is critically dependent on the concentration of modifiers (e. g. the negative effectors ATP, ADP, AMP, uridine diphosphate and inorganic phosphate, or the positive effectors glucose 6-phosphate, uridine diphospho-glucose and $\mathrm{Mg}^{2+}$ ) [25]. The crude muscle homogenates prepared in this study contain unknown amounts of effectors and cofactors. Therefore, while intrinsic enzyme activity was significantly reduced under optimal conditions, the net effect on in vivo function will depend also on any changes to these modifiers that has occurred with ADR treatment.

At the dose of ADR used in this study we did not detect any acute change in glycogen phosphorylase $a$ activity. Earlier in vitro studies using rat hemidiaphragm have also linked inhibition of glucose uptake by ADR to decreased glycogen synthesis rather than increased glycogen breakdown $[29,30]$. More recently infusion of ADR in man (with a higher dose over a shorter time frame than our study) was shown to increase phosphorylase $a$, although total activity was unchanged [11]. As with glycogen synthase, in vivo glycogen phosphorylase activity is determined by factors additional to intrinsic enzyme activity. In the case of glycogen phosphorylase, inorganic phosphate concentration has a major influence and may be lowered by hexose monophosphate accumulation. Thus, increased intrinsic activity does not necessarily correlate with increased in vivo activity. In our study, the reduced glycogen synthase and unchanged glycogen phosphorylase activities during acute $A D R$ would by themselves result in net loss of glycogen, but if the rate of loss was constant over $74 \mathrm{~h}$, then at $2 \mathrm{~h}$ there would be less than $3 \%$ of the final reduction. This change would be insufficient to allow detection.

The issue of inhibition of glycolysis by ADR, with accumulation of glycolytic intermediates and consequent impairment of hexokinase activity was also addressed in this study. Glucose 6-phosphate tended to rise but the increase was not significant. Fructose 6-phosphate tended to fall and furthermore, hexokinase activity was not inhibited. However, the physiological dose of ADR used in this study did not produce significant hyperglycaemia or hyperinsulinaemia and so the only increase of glucose 6-phosphate input would be from glycogenolysis. Previous studies, which have shown accumulation of hexose monophosphates, have involved hyperglycaemia or hyperinsulinaemia with increased transmembrane glucose transport [10]. A recent report of enhanced glycolysis due to $\mathrm{ADR}$ during hyperinsulinaemic glucose clamp studies, did show accumulation of glucose 6-phosphate due to marked reduction of glycogenesis [31]. Another study which addressed the actions of ADR alone, used a three-fold higher dose than in our study and the increase of hexose monophosphates was likely to be related to a higher rate of glycogenolysis [11].

The key enzyme of the glycolytic pathway is phosphofructokinase and ADR is known to have both direct and indirect effects on phosphofructokinase function. In per-' fused rat heart $\mathrm{ADR}$ activated phosphofructokinase by a cyclic AMP independent mechanism [32]. In human skeletal muscle during a hyperinsulinaemic euglycaemic clamp, ADR increased glucose, 1,6-bisphosphate and fructose 6-phosphate which are activators of phosphofructokinase, but had no effect on fructose 2, 6-bisphosphate [31]. We found reduced $V_{\max }$ during 2-h ADR infusion which suggests some reduction. However, the level of phosphofructokinase was still well above the maximal operating rate of the enzyme in vivo and would therefore not affect the rate of glycolysis. Thus, acute elevation of ADR to levels found in severe physical stress produced enzyme changes conducive to glycogenolysis, but no changes likely to alter glycolytic activity.

With long-term in vivo elevation of $A D R$, there were different effects on the enzymes of skeletal muscle glucose metabolism. Glycogen synthase I levels returned to baseline but there was now a significant increase of phosphorylase $a$ activity, and a significantly decreased $\mathrm{K}_{\mathrm{m}} a$, reflecting an increased binding affinity of the enzyme for the substrate, presumably secondary to formation of phosphorylase kinase a [33] or phosphorylation of the protein termed inhibitor-1 which inhibits phosphorylase phosphatase [34]. The net result would be to favour glycogenolysis and consistent with this effect, glycogen stores were significantly depleted by the long-term infusion. However, the observed changes of enzyme activity in vitro do not correlate well with the amount of glycogen loss over $74 \mathrm{~h}$. In vivo enzymatic activity influenced by changes in effectors and cofactors is likely to differ significantly from the in vitro activity. In addition, the time course of changes in enzymatic activity is not known. Long-term elevation of ADR did not appear to impair glycolysis. There was not significant accumulation of hexose monophosphates or inhibition of hexokinase. In fact phosphofructokinase had significantly reduced $\mathrm{K}_{\mathrm{m}}$ which would favour enhanced glycolytic activity at physiological concentrations of fructose 6-phosphate.

The changes of enzymes and substrates with long-term vs short-term elevation of ADR indicated similar overall effects, namely enhanced glycogenolysis and unimpaired glycolysis which would be substrate driven. However, there were differences in the mechanisms for these effects between short-term and long-term elevations of ADR. These differences could represent modulation of the direct effects of ADR on skeletal muscle, due to a change such as desensitisation of $\beta$-adrenergic receptors following prolonged ADR exposure [35]. Similarly the trend towards increased ADR levels during chronic compared with acute infusion could represent reduced clearance by $\beta$ adrenergic receptor related mechanisms [36, 37]. On the other hand, the differing effects with time of ADR on 
skeletal muscle may relate to an indirect action mediated by alteration of insulin secretion. Our earlier in vivo studies did not show an effect of ADR in impairing insulin secretion in response to intravenous glucose [15], but more detailed testing of insulin secretion would be required to exclude a role for altered Beta-cell function. Blood flow is another important factor to consider as a mediator of the metabolic effects of ADR [38]. Altered blood flow could influence availability of glucose and other metabolites, as well as insulin access to tissues. Muscle blood flow may differ during short- and long-term adrenaline infusion but has not been studied under these conditions.

There are several similarities between the results of this study and our previous in vivo studies of determinants of glucose tolerance during short- and long-term ADR infusions [15]. Some of the acute effects of ADR, such as reduced glycogen synthase I activity, were attenuated with prolonged infusion, following the same pattern as insulin sensitivity in the previous studies. Other aspects of glucose metabolism, such as increased glycogen phosphorylase $a$ activity altered more with prolonged than acute ADR infusion, as did glucose-mediated glucose disposal [16] in the earlier studies. We did not, however, demonstrate significant accumulation of hexose monophosphate or inhibition of hexokinase, which are thought to be likely mechanisms for ADR induced impairment of glucose transport. Nevertheless, in the absence of significant hyperglycaemia or hyperinsulinaemia, glycolytic flux may have been insufficient to produce this result. The effect of ADR in vivo to impair glucose disposal is more pronounced in situations of elevated glucose and insulin levels than with infusion of ADR alone and our results are consistent with these differences between situations of high and low glycolytic flux.

Acknowledgements. We are grateful to Mr. S. Sawyer and Ms. S. Patton of the Endocrine Laboratory, and the staff of the Experimental Medical and Surgical Unit for assistance with hormone assays and the care of the experimental animals respectively. We thank Ms. N. Hayes for secretarial assistance and Dr. J.Frayne for assistance with the muscle biopsy technique. This work was supported by the National Health and Medical Research Council of Australia, the Kellion Diabetes Foundation of Australia and the St. Vincent's Hospital Research Fund.

\section{References}

1. Woods SC, Smith PH, Porte D Jr (1980) The role of the nervous system in metabolic regulation and its effects on diabetes and obesity. In: Brownlee M (ed) Handbook of diabetes mellitus. Intermediary metabolism and its regulation, Vol 3. Garland, New York, pp 209-271

2. Rizza R, Cryer PE, Haymond M, Gerich J (1980) Adrenergic mechanisms for the effects of epinephrine on glucose production and clearance in man. J Clin Invest 65: 682-689

3. Porte D Jr (1967) A receptor mechanism for the inhibition of insulin release by epinephrine in man. J Clin Invest $46: 86-94$

4. Young JB, Landsberg L (1977) Catecholamines and intermediary metabolism. Clin Endocrinol Melab 6: 599-631

5. Shulman GI, Rothman DL, Jue T, Stein P, DeFronzo RA, Shulman RG (1990) Quantitation of muscle glycogen synthesis in normal subjects and subjects with non-insulin-dependent diabetes by ${ }^{13} \mathrm{C}$ nuclear magnetic resonance spectroscopy. $\mathrm{N}$ Engl J Med 322: 223-228

6. Walaas O, Walaas E (1950) Effect of epinephrine on rat diaphragm. J Biol Chem 187:769-776

7. Bihler I, Sawh PC, Sloan IG (1978) Dual effect of adrenalin on sugar transport in rat diaphragm muscle. Biochim Biophys Acta 510:349-360

8. Sloan IG, Sawh PC, Bihler I (1978) Influence of adrenalin on sugar transport in soleus, a red skeletal muscle. Mol Cell Endocrinol 10: 3-12

9. Chiasson J-L, Shikama H, Chu DTW, Exton JH (1981) Inhibitory effect of epinephrine on insulin-stimulated glucose uptake by rat skeletal muscle. J Clin Invest 68: 706-713

10. James DE, Burleigh KM, Kraegen EW (1986) In vivo glucose metabolism in individual tissues of the rat. Interaction between epinephrine and insulin. J Biol Chem 261: 6366-6374

11. Chasiotis D, Sahlin K, Hultman E (1983) Regulation of glycogenolysis in human muscle in response to epinephrine infusion. $\mathrm{J}$ Appl Physiol: Respirat Environ Exercise Physiol 54: 45-50

12. Lueck JD, Fromm HJ (1974) Kinetics, mechanism, and regulation of rat skeletal muscle hexokinase. J Biol Chem 249:1341-1347

13. Young AA, Bogardus C, Stone K, Mott D (1988) Insulin response of components of whole body and muscle carbohydrate metabolism in humans. Am J Physiol 254: E231-E236

14. Budohoski L, Challis RAJ, Dubaniewicz A et al. (1987) Effects of prolonged elevation of plasma adrenaline concentration in vivo on insulin sensitivity in soleus muscle of the rat. Biochem $\mathbf{J}$ 244: 655-660

15. Martin IK, Weber KM, Boston RC, Alford FP, Best JD (1988) Effects of epinephrine infusion on determinants of intravenous glucose tolerance in dogs. Am J Physiol 255: E668-E673

16. Ader M, Pacini G, Yang Y, Bergman RN (1985) Importance of glucose per se to intravenous glucose tolerance: comparison of the minimal-model prediction with direct measurements. Diabetes 34: 1092-1102

17. Barnard RJ, Edgerton VR, Furukawa T, Peter JB (1971) Histochemical, biochemical and contractile properties of red, white, and intermediate fibers. Am J Physiol 220: 410-414

18. Doery JCG, Hirsh J, De Gruchy GC (1970) Platelet glycolytic enzymes: effect of cellular disruption procedures on activity. Br J Haem 19: 145-147

19. Bergmeyer J-U (1984) Phosphorylase a. In: Bergmeyer H-U (ed) Methods of enzymatic analysis, Vol II. Verlag Chemie, Weinheim, pp 293-295

20. Danforth WH (1965) Glycogen synthetase activity in skeletal muscle. Interconversion of two forms and control of glycogen synthesis. J Biol Chem 240: 588-593

21. Kornfeld R, Brown DH (1962) Preparation and properties of uridine diphosphate glucose-glycogen transglucosylase. J Biol Chem 237:1772-1777

22. King RFGJ, Macfie J, Hill G (1981) Activities of hexokinase, phosphofructokinase, fructose bisphosphatase and 2-oxoglutarate dehydrogenase in muscle of normal subjects and very ill surgical patients. Clin Sci 60: 451-456

23. Keppler D, Decker K (1984) Glycogen. In: Bergmeyer H-U (ed) Methods of enzymatic analysis, Vol VI. Verlag Chemie, Weinheim, pp 11-17

24. Gerhard M (1984) D-Glucose 6-phosphate and D-fructose 6-phosphate. In: Bergmeyer H-U (ed) Methods of enzymatic analysis, Vol VI. Verlag Chemie, Weinheim, pp 191-197

25. Roach PJ, Takeda Y, Lamer J (1976) Rabbit skeletal muscle glycogen synthase. I. Relationship between phosphorylation state and kinetic properties. J Biol Chem 251: 1913-1919

26. Dietz MR, Chiasson JL, Soderling TR, Exton JH (1980) Epinephrine regulation of skeletal muscle glycogen metabolism. J Biol Chem 255: 2301-2307

27. Wolfe RR, Herndon DN, Jahoor F, Mujoshi H, Wolfe M (1987) Effect of severe burn injury on substrate cycling by glucose and fatty acids. N Engl J Med 317: 403-408

28. Sheorain VS, Juhl H, Bass M, Soderling TR (1984) Effects of epinephrine, diabetes, and insulin on rat skeletal muscle gly- 
cogen synthase. Phosphorylation site occupancies. J Biol Chem 259: $7024-7030$

29. Walaas $E$ (1955) The effect of adrenaline on the uptake of glucose, mannose and fructose in the rat diaphragm. Acta Phys Scandinav 35: 109-125

30. Haugaard E, Davidheiser S, Haugaard N (1976) Effect of epinephrine and cyclic AMP phosphodiesterase inhibitors on the glycogen synthetic pathway and glucose content in skeletal muscle. Biochem Pharm 25: 439-445

31. Raz I, Katz A, Spencer MK (1991) Epinephrine inhibits insulinmediated glycogenesis but enhances glycolysis in human skeletal muscle. Am J Physiol 260: E430-435

32. Clark MG, Patten GS (1981) Adrenaline activation of phosphofructokinase in rat heart mediated by $\alpha$-receptor mechanism independent of cyclic AMP. Nature 292: 461-463

33. Yeaman SJ, Cohen P (1975) The hormonal control of activity of skeletal muscle phosphorylase kinase. Phosphorylation of the enzyme at two sites in vivo in response to adrenalin. Eur $J$ Biochem 51: 93-104

34. Foulkes JG, Jefferson LS, Cohen P (1980) The hormonal control of glycogen metabolism: dephosphorylation of protein phosphatase inhibitor-1 in vivo in response to insulin. FEBS Lett 112:2124
35. Snavely MD, Mahan LC, O'Connor DT, Insel PA (1983) Selective down-regulation of adrenergic receptor subtypes in tissues from rats with pheochromocytoma. Endocrinology 113:354-361

36. Cryer PE, Rizza RA, Haymond MW, Gerich JE (1980) Epinephrine and norephinephrine are cleared through $\beta$-adrenergic, but not $\alpha$-adrenergic, mechanisms in man. Metabolism 29:1114 1118

37. Best JD, Haiter JB (1982) Release and clearance rates of epinephrine in man: importance of arterial measurements. J Clin Endo Metab 55: 263-268

38. Laakso M, Edelman S, Brechtel G, Baron A (1990) Mechanism of epinephrine induced insulin resistance in man. Diabetes $39: 22$ (Abstract)

Received: 26 September 1991

and in revised form: 2 December 1991

Dr.J.D.Best

University of Melbourne

Department of Medicine

St. Vincent's Hospital

Fitzroy, Victoria 3065

Australia 